\title{
COMPARISON OF SHORT-TERM TEMPERATURE FORECASTING BETWEEN ARTIFICIAL NEURAL NETWORK AND MACHINE LEARNING.
}

Flavio Santos Conterato, Caique Augusto Cardoso de Moraes, Grhamm Pabsta, João Felipe de Araújo Caldas ${ }^{a}$, Matheus Carvalho Nascimento de Souzaa, Davidson Martins Moreira ${ }^{2}$ Erick Giovani Sperandio Nascimento ${ }^{a}$

a SENAI CIMATEC University Center, Brazil

\begin{abstract}
The objective of this work was to evaluate an optimized ANN (Artificial Neural Network) model compared to the most famous basic regression models within Machine Learning, using a set of observational data collected in an anemometric tower located in the city of Mucuri, Bahia, in northeastern Brazil, within one month. To obtain results for comparison of the models, the proposed activity was to forecast the temperature in 1 hour ahead, as a contribution to the city's agricultural sector. Among all the analyzed models, the one that proved most efficient was the ANN with 4 layers ( 7 nodes in the input layer, 18 and 9 respectively in the 2 hidden layers, and 1 in the output layer), based on $\mathrm{R}(0.872)$.
\end{abstract}

Keywords: Computational Intelligence; Artificial Neural Networks; Temperature; Temperature Forecast; Machine Learning.

\section{COMPARAÇÃO DA PREVISÃO DA TEMPERATURA A CURTO PRAZO ENTRE REDE NEURAL ARTIFICIAL E APRENDIZADO DE MÁQUINA.}

Resumo: O objetivo deste trabalho foi avaliar um modelo de RNA (Rede Neural Artificial) otimizado em comparação com os mais famosos modelos básicos de regressão para Machine Learning, utilizando um conjunto de dados observacionais coletados em uma torre anemométrica localizada na cidade de Mucuri, Bahia, no nordeste do Brasil, em um mês. Para obter resultados para comparação dos modelos, a atividade proposta foi prever a temperatura em 1 hora, como contribuição para o setor agrícola da cidade. Dentre os modelos analisados, o que se mostrou mais eficiente foi a RNA com 4 camadas ( 7 nós na camada de entrada, 18 e 9 respectivamente nas duas camadas ocultas e 1 na camada de saída), com base na melhor métrica, Coeficiente de Pearson R (0.872)

Palavras-chave: Inteligência Computacional; Redes Neurais Artificiais; Temperatura; Previsão de Temperatura; Aprendizado de Máquina. 


\section{INTRODUCTION}

Weather-related forecasts have been presented to be a reliable ally in the preparation for cyclones and other climate catastrophes before they arrive in cities. Moreover, the atmospheric temperature is an important variable in weather forecasting, and anticipating the temperature is important for seasonal commercial and agriculture planning, and together with other variables like air humidity, wind, atmospheric pressure and precipitation could be helpful in a large number of situations [1]. Forecasts can be made using time series methods, linear regression, some mathematical models, and of course the ANN (Artificial Neural Network), each model used to make a forecast about the temperature.

The goal of this study is to document the reliability of a MLP (Multilayer Perceptron) in comparison with the other models of traditional machine learning, concerning the benefits of the correct forecast about the temperature. The literature recommends the MLP being used for complex data regressions [2], as exhibiting a high precision in all the achieved results.

For cities with high growth in agriculture and the industrial sector such as the city of Mucuri [3], tools like this prove to be low-cost, high-performance and very useful alternatives for planning and decision-making. The procedure brings a reliable forecast with a low error rate, but the data used for training the network was obtained from an anemometric tower, which is usually located at 100 meters high. The data was used because the data set originated from a project that measures wind speed and temperature, therefore, it is recommended to train the ANN with surface data to obtain more accurate results.

\section{METHODOLOGY}

For this study, an Artificial Neural Network (ANN) for regression of the MLP type was created using Python and Keras (with Tensorflow) to be compared with some regression models of machine learning from the SKLearn library. The study refers to a temperature forecast applied to a collection of meteorological data from the city of Mucuri - BA in Brazil, with the forecast made for one hour after the recorded temperature. The city was chosen due to the largest Brazilian pole of investments in wind energy, with $70 \%$ of Mucuri's economy driven by the industrial sector [3]. According to data from IBGE (Brazilian Institute of Geography and Statistics) [4], the city is located in an Atlantic Forest biome.

For the construction of the ANN, tests were made with different configurations, and the ones with more accurate results were applied together with the dataset selected, following the concept where the ANN is commonly used with at least 3 layers [5]. As demonstrated in the Figure 1, 2 hidden layers were used, both with the "sigmoid" activation function because it presented the best performance. In the output layer, the "linear" activation function was chosen since the MinMaxScaler normalization (between -1 and 1) was used only in the input data, holding non-normalized output data. Mean Square Error (MSE) loss function with a SGD (Stochastic Gradient Descent) Optimizer that provided the best results. Besides, the best number of seasons and the learning rate that was obtained were 1000 epochs with a 0.01 rate. 
Figure 1. ANN Configuration

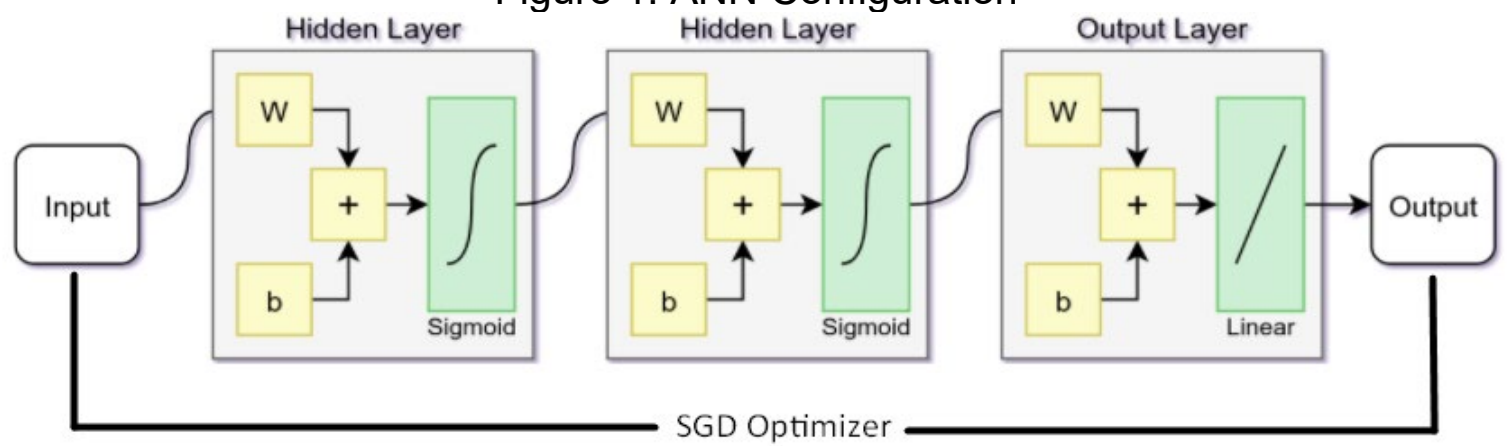

Regarding metrics used, as depicted [6]:

$$
M S E=\frac{1}{n} \sum_{t=1}^{n} e_{t}^{2}
$$

MSE is the Mean Squared Error and $n$ is the number of time instances.

$$
M A E=\frac{1}{n} \sum_{t=1}^{n}\left|e_{t}\right|
$$

MAE is the Mean Absolute Error and $n$ is the number of time instances.

$$
R^{2}=\frac{\sum_{i=1}^{n}\left(\widehat{y}_{l}-\bar{y}\right)^{2}}{\sum_{i=1}^{n}\left(y_{i}-\bar{y}\right)^{2}}
$$

$\mathrm{R}^{2}$ is the regression coefficient, $y_{i}$ is the observable value, $\bar{y}$ is the average of the observations, $\hat{y}_{i}$ is the prediction of $y_{i}, n$ is the amount of data.

$$
R=\frac{\sum_{i=1}^{n}\left(x_{i}-\bar{x}\right)\left(y_{i}-\bar{y}\right)}{\sqrt{\sum_{i=1}^{n}\left(x_{i}-\bar{x}\right)^{2} \sum_{i=1}^{n}\left(y_{i}-\bar{y}\right)^{2}}}
$$

$\mathrm{R}$ is Pearson's correlation coefficient, $x_{i}$ is the data in the first matrix in the equation, $y_{i}$ is the data in the second matrix in the equation, $\bar{x}$ is the average of the data in the first matrix, $\bar{y}$ is the average of the data in the second matrix and $n$ is the amount of data used.

As for statistical regression metrics, they are used to measure the quality of the forecast, as stated by Felix (2010, p.68): "Statistics are described to assess the performance of the forecasting model. That is, from the comparison of the actual values and the values "adjusted" by the model, several metrics could be calculated to measure performance. These measures are then used to assess the performance of the model estimated in (in sample) and out (out of sample) of the small amount of data used in the modeling" [7].

\section{RESULTS AND DISCUSSION}

For the conceptualization of ANN architecture, it was taken into account what was said in another article of a similar objective [6]. A large number of hidden layers 
may propagate error further and further into the model, and the number of neurons must be decided empirically, for there is no way to be calculated or theorized beforehand [8].

For the model's parameters and structure, the ANN was assembled with the following nodes and layers.

Figure 2. ANN Layers

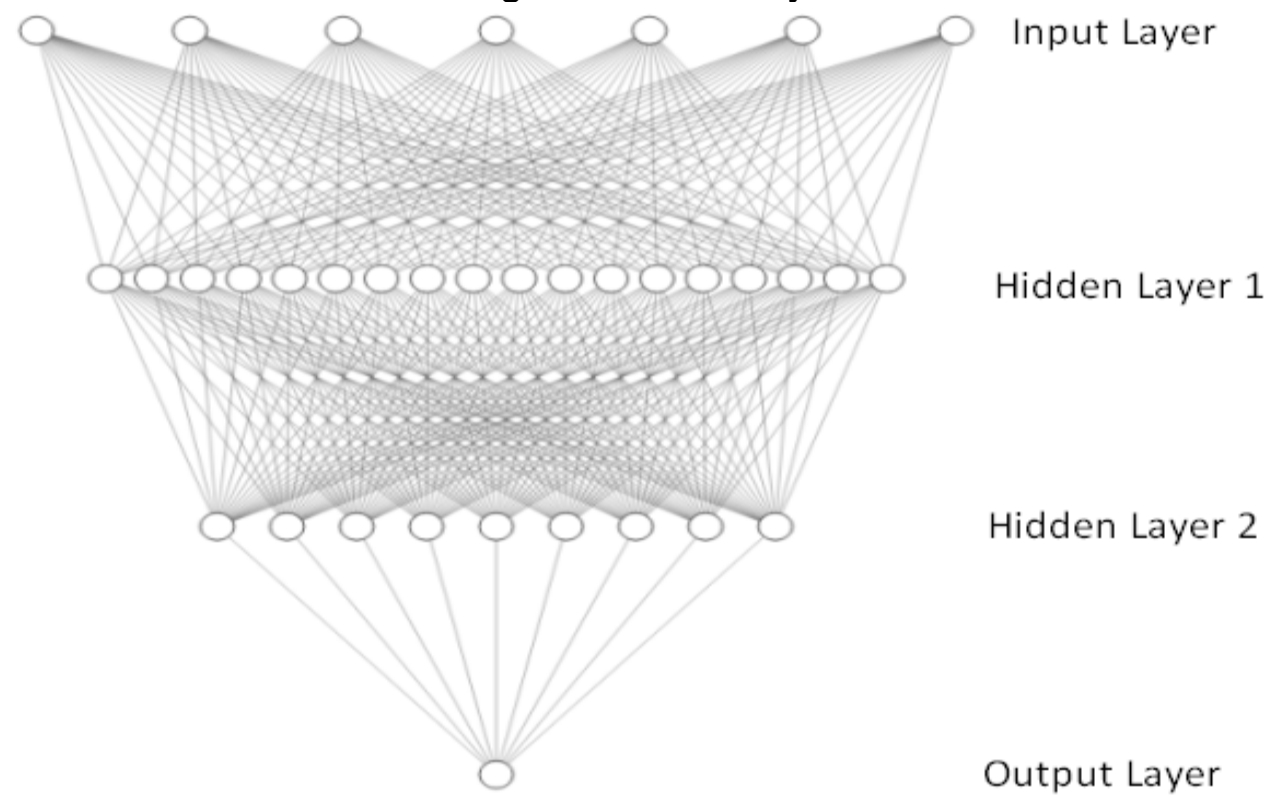

After training, the artificial neural network was presented to a set of data to perform the test as such the model used the temperature of the city of Mucuri recorded at the time to forecast the temperature of the next hour, reaching the result demonstrated in Figure 3.

Figure 3: Real and forecast temperature time series.

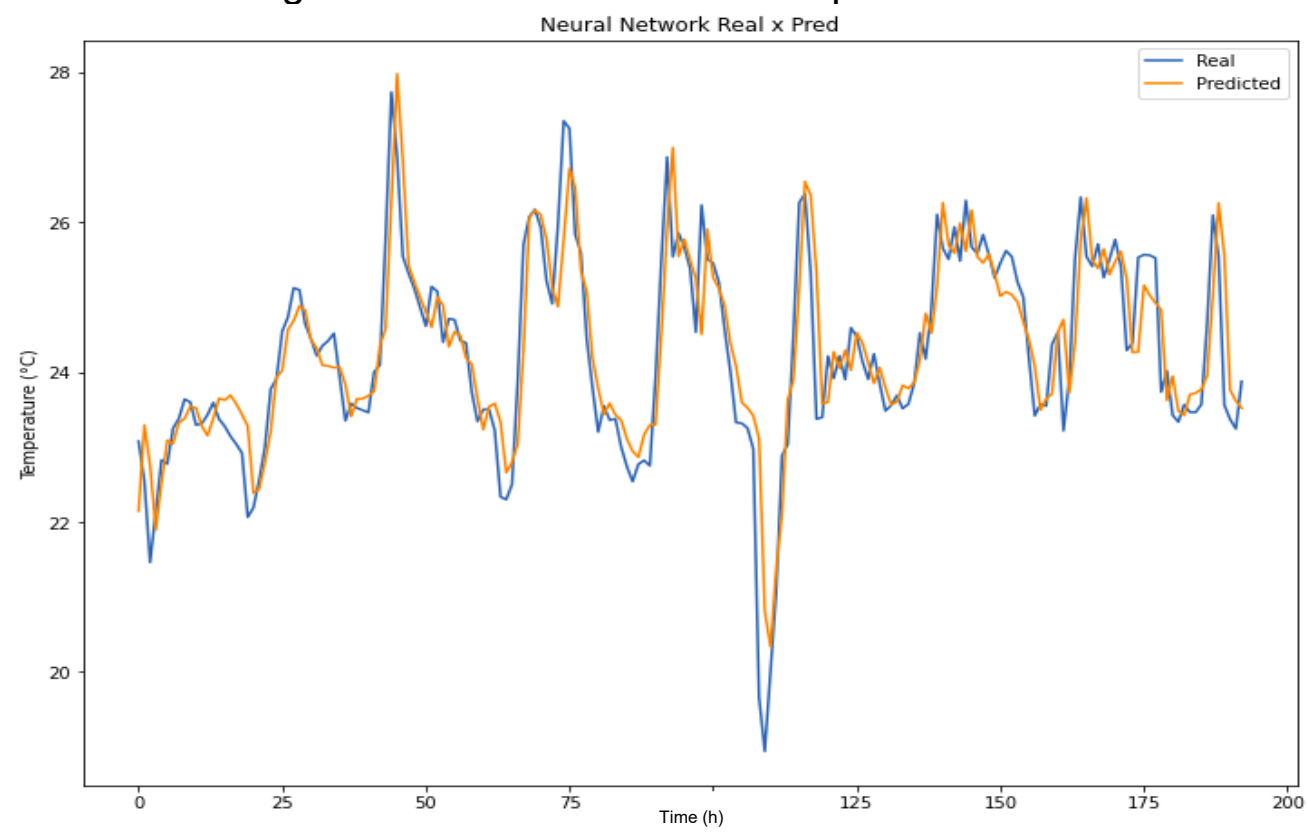


Next, in Figure 4, the result of this forecast in the factor of 2 is exhibited, considering the $\mathrm{Y}$-axis as the forecast temperature and the $\mathrm{X}$-axis as the temperature recorded at the time.

Figure 4: Real and forecast temperature (factor of 2).

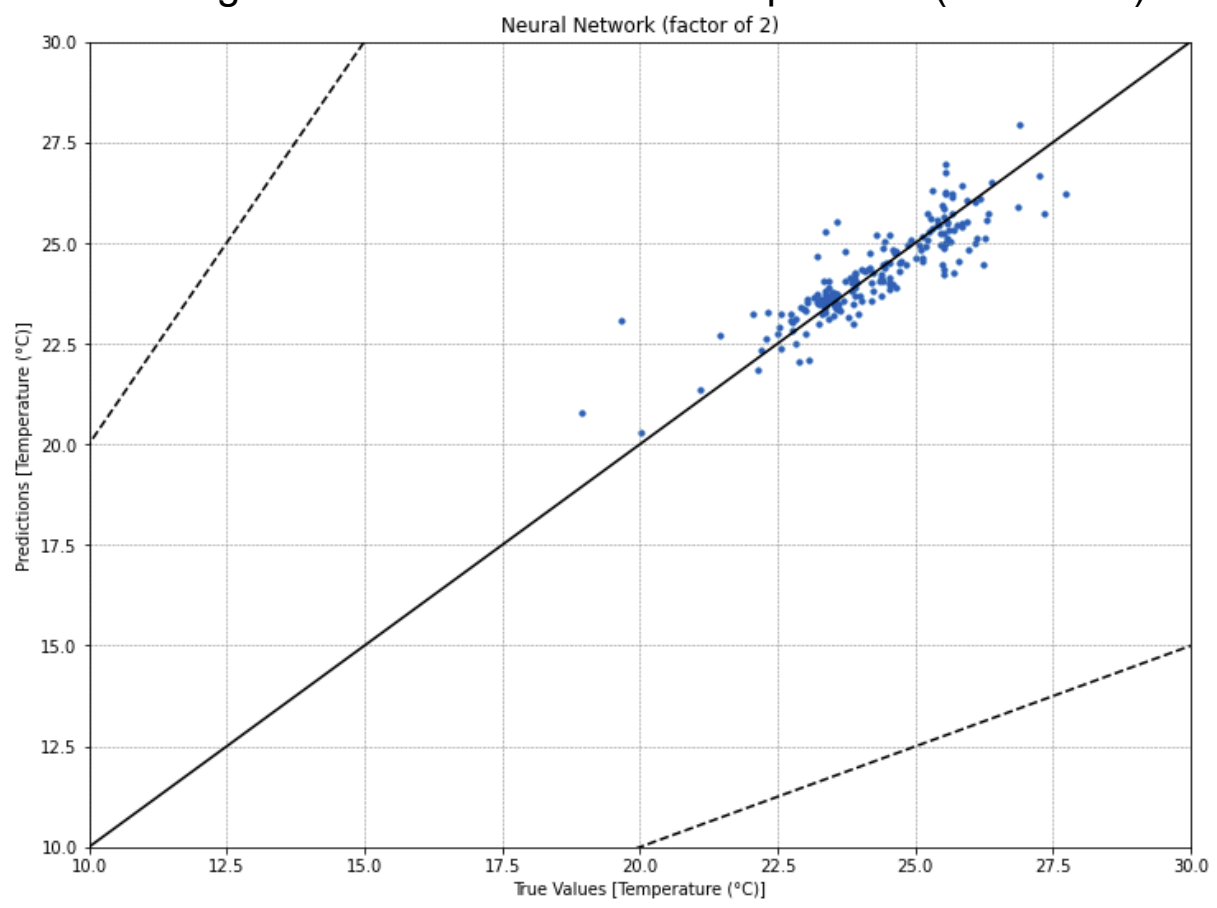

In table 1, the comparison of the metrics utilized in each regression method are highlighted, thereby measuring the efficiency of each method.

Table 1. Comparison between the metrics of the methods

\begin{tabular}{|c|c|c|c|c|c|}
\hline Regression & MAE & MSE & \multicolumn{1}{|c|}{$\mathbf{R}$} & $\mathbf{R}^{2}$ & Factor of 2 \\
\hline ANN & 0.467 & 0.425 & 0.872 & 0.760 & 1.0 \\
\hline KNNREG & 0.781 & 0.947 & 0.738 & 0.465 & 1.0 \\
\hline LINEAR REG & 0.507 & 0.533 & 0.845 & 0.699 & 1.0 \\
\hline GradBoost REG & 0.474 & 0.462 & 0.863 & 0.739 & 1.0 \\
\hline KernelRidge & 2.859 & 12.214 & 0.282 & -5.885 & 1.0 \\
\hline Polynomial REG & 0.500 & 0.461 & 0.887 & 0.781 & 1.0 \\
\hline
\end{tabular}

When observing the resulting metrics of the regression metrics, it can be noticed that the neural network had the best results on average. It reached satisfactory results, 
such as the MSE (used as the loss function during the training of the ANN model) which was the best in general among the models.

\section{CONCLUSION}

The growing number of industries in Mucuri encourages the search for technologies to guarantee production, such as efficient forecast tools. By observing the captured and analyzed aspects, it was possible to perceive the main differences of the presented models in the short-term forecast of the temperature of 1 hour. From the results, it is observed that among the studied models present in the document, the one that remained with the highest quality was the Computational Intelligence methodology focused on Al using a Multi-layer Artificial Neural Network with 4 layers, having 7 inputs with 18 and 9 neurons in the respective hidden layers and 1 output. It was additionally the one that presented the most satisfactory result regarding the calculation of the metrics used MAE (0.467), MSE (0.425), Pearson's correlation coefficient R (0.872) and $\mathrm{R}^{2}$ regression coefficient $(0.760)$.

The model ANN presented the least error when being tested for the forecast made in the proposal in question, in contrast to the other models used. To use in the industrial environment, the intention is to improve these technologies, therefore, it is necessary to reformulate the proposed model to medium-long forecast, then allowing greater security for the performance of activities without unexpected losses.

\section{Acknowledgments}

The authors would like to thank the SENAI CIMATEC, in particular, the Graduate Program in Computation Engineering, SENAI CIMATEC University Center and the Voluntary Study Program for Artificial Intelligence and Computational Modeling Software's Environment.

\section{REFERENCES}

${ }^{1}$ SOUTO, Ana Lucia. Importância da previsão do tempo. Available in: https://pt.khanacademy.org/science/8-ano/clima-fenomenos-meteorologicosprevisao-tempo/fenomenos-meteorologicos-previsao-do-tempo/a/importancia-daprevisao-do-tempo. Access in: 22 jul. 2020.

${ }^{2}$ Kim, Taehwan \& Adali, Tülay. (2001). Approximation by fully complex MLP using elementary transcendental activation functions. Neural Networks for Signal Processing - Proceedings of the IEEE Workshop. 203 - 212.

10.1109/NNSP.2001.943125. Available in:

https://www.researchgate.net/publication/3910413_Approximation_by_fully_complex _MLP_using_elementary_transcendental_activation_functions/citation/download. $\bar{A}$ ccess in: 19 de jul. 2020. 
${ }^{3}$ Com 41 mil habitantes, cidade no sul da Bahia lidera exportações na região e tem $\mathbf{7 0} \%$ da economia movida pela indústria. Available in:

https://g1.globo.com/ba/bahia/avanca/noticia/2019/05/18/com-41-mil-habitantescidade-no-sul-da-bahia-lidera-exportacoes-na-regiao-e-tem-70percent-da-economiamovida-pela-industria.ghtml. Access in: 22 jul. 2020.

${ }^{4}$ IBGE, Instituto Brasileiro de Geografia e Estatística. Mucuri. Available in:

https://www.ibge.gov.br/cidades-e-estados/ba/mucuri.html. Access in: 18 jul 2020.

${ }^{5}$ BABOO, Dr. S. Santhosh et al. An Efficient Weather Forecasting System using Artificial Neural Network, International Journal of Environmental Science and Development, p. 1-6, 4 nov. 2010. Available in: http://www.ijesd.org/papers/63D472.pdf. Access in: 20 jul. 2020.

${ }^{6}$ Zucatelli, Pedro et al. (2018). PREVISÃO DA VELOCIDADE DO VENTO A CURTO PRAZO USANDO REDES NEURAIS ARTIFICIAIS EM MUCURI, BAHIA.

10.26678/ABCM.CONEM2018.CON18-0393. Available in:

https://www.researchgate.net/publication/326045477_PREVISAO_DA_VELOCIDAD E_DO_VENTO_A_CURTO_PRAZO_USANDO_REDES_NEURAIS_ARTIFICIAIS_E M_MUCURI_BÄHIA. Access in: 18 de jul. 2020.

${ }^{7}$ FELIX, Ricardo. Fundos de Pensão Públicos X Fundos de Pensão Privado: Qual será o perfil do investimento?. Available in: https://www.maxwell.vrac.pucrio.br/16513/16513_5.PDF. Access in: 23 jul. 2020.

${ }^{8}$ ZUCATELLI, P.J. et al. Short-term wind speed forecasting in Uruguay using computational intelligence, Colonia Eulacio, Soriano Department, Uruguay, v. 5, p. 1-11, may 2019. DOI https://doi.org/10.1016/j.heliyon.2019.e01664. Available in: https://reader.elsevier.com/reader/sd/pii/S2405844018368087?token=E2A6CFCAC3 977E342F98D8B8C7E52B0C81BE7C5FF8BE699258CF5E9DA724CEE60BA3EB34 6BFDBDCEE018D65A7A52A338. Access in: 9 aug. 2020. 